\title{
Chasing Funds: \\ Start-ups from a Global Value Chains Approach
}

\author{
Simone Wolff, University of Londrina, ${ }^{1}$ Brazil
}

\begin{abstract}
This article investigates the role of Brazilian legislation in the (re)production of subordinate forms of incorporation of peripheral countries in global value chains (GVCs) through new dynamics for the extraction of value intermediated by international systems of investment. The purpose is to show how financial deregulation contributes to "putting-out" research and development (R\&D) labs of major brands, and serves as a way of exploring casual and flexible hiring schemes for skilled workers. To this end, the article explores the financing policies for the Brazilian innovation system, whose aim is to promote the inclusion of higher value-added activities in the GVCs through the connection of national innovative micro-enterprises to direct financial investments, a strategy considered fundamental to boost the country's industrialisation. The analysis focuses on two Calls for Funds for technology-based start-ups, a category of micro-business where investments have been stimulated due to such policies. The results reveal how leading companies in global value chains have been using this rentier development model to reduce costs in R\&D activities by sharing the risks of innovation and transferring labour charges to start-ups, advancing the casualisation of work for skilled workers. In this context, casual employment with no labour rights has turned countries at a low level of industrialisation, like Brazil, into an attraction to the dynamics of the CGVs.
\end{abstract}

\section{KEYWORDS}

Start-ups; global value chains; production funding; casualisation of work; putting-out system

\section{Introduction}

Global value chains (GVCs) have been the utmost representation of capital globalisation over four decades of free worldwide economy. This approach has enabled us to understand how economic liberation favoured the transfer of a whole range of manufacturing and trade activities to countries other than those where the brand and patent owners are located (Gereffi, 1999). This conception comes from seminal studies by Hopkins and Wallerstein (1986) who brought capitalism in its historical expansion phase into perspective in order to understand spatial inequalities and the role of the state within this context. Based on the concept of global commodity chains (GCC), they analysed global production networks so as to highlight that these asymmetries are corollary to unequal relations of power between central and peripheral states and their foreign trade tariffs and regulations.

With the liberation of foreign trade, Gereffi $(1999,2005)$ updates this understanding by

${ }^{1}$ This article is a result of the author's post-doctoral internship at the Institute of Economy, University of Campinas (UNICAMP), Brazil. 
changing the focus from state-nation to the new asymmetries caused by the leading companies in the world market as they coordinate such networks within national territories. Emphasis relies on unequal relations of value appropriation throughout the chains in which activities of more aggregated value (control and coordination) are concentrated in central countries, whereas those of low aggregated value (design, marketing, assembly and commercialisation) are shifted to peripheral countries.

The concept of governance framework has been an innovation in this analytical scenario as the dimension of territoriality and the systems of input and output of the chains also allow for addressing the institutional contexts that influence them. According to Gereffi (1994: 97), governance is understood as "relations of authority and power that define how financial, material and human resources are placed and flow within a chain". In this conjuncture, transaction costs became rather relevant as the role of the state in the definition of customs rules and tariffs was weakened and liaisons of trust for the externalisation of global companies became more necessary (Gereffi, 2005).

The analysis here is refined in order to show the prevalence of consumption over production, and the use of just-in-time methods in several links of these chains; that is a circumstance not found in the first studies about GCCs. The methodology, therefore, reaches the concept of global value chains. The term commodity, restricted to non-differentiated, low-added-value products, was replaced by the word value so as to encompass the customised products. It has been replaced as well because it allows for the perception of added value and the idea of its progression throughout the chains and up to the final product through the customisation of processes and products (Gereffi, 2005).

More critical approaches to this conceptual scenario have brought in the perspective of workers and demonstrated that the integration of peripheral countries into GVCs has resulted in precarious work (Huws et al., 2009; Anner, 2011; Flecker., 2016; Wolff, 2019). In Latin America, many of these approaches follow the theories of dependent development and imperialism and highlight the role of the state in re-establishing unequal relations between centre and periphery in these chains (Palma, 1978; Patel-Campillo, 2010). Nevertheless, due to the predominance of commodity production in peripheral countries, researches have been focusing on the consequences of this integration to the sectors of low aggregated value (Kaltmeier et al., 2020). In Brazil, predominant methodology has been restricted to measuring the level of engagement of the country in GVCs (Oliveira, Carneiro and Silva Filho, 2017). These analyses reiterate the neo-liberal doctrine as they automatically link national development to greater economic liberalisation.

Contrary to this perspective, this study aims to contribute to the debate about the performance of GVCs in peripheral countries as it focuses on the activities of greater added-value and how their specific governance frameworks cause unequal value appropriation along these chains. This perspective highlights the way financial deregulation has (re)produced subordinate forms for the incorporation of peripheral countries to the circuits of CGVs through direct funding policies that enable the use of new models of business in innovation activities. These are investments that connect leading corporations from the GVCs to the demands and operations that are needed in order to take their products and services to the end markets.

The purpose is to design a critical analysis of GVCs as a methodological resource to reveal how the new strategies for outsourcing research and development (R\&D) laboratories are implemented by financial capital and how this financialisation of production hides a piecework wage system set by just-in-time work. Therefore, it analyses the Brazilian regulatory system for the high technology sector in its attempt to internationalise the country's innovative micro-enterprises by connecting them to international investment systems. 
In Brazil, the most used instrument to raise these resources are the Calls for Joint Innovation Funds, which are managed by policies that promote the national productive system, within a governance model based on public-private partnerships. These Calls for Funds aim to institutionalise joint ventures between private investors and micro-companies with proposals for innovative technological projects. The purpose is to stimulate greater-value-added activities that can promote the qualified insertion of the country into the financial routes of the GVCs. This strategy has become part of governmental and business discourses as a fundamental leverage for Brazilian industrialisation (Oliveira et al., 2017).

Drawing from the analysis of such policies and of two Calls for Funds for technology-based start-ups, a category of micro-business where investments have been most prominent, this investigation intends to show how the financial logic contributes to a dynamic of extraction and appropriation of value for the leading companies from the GVCs while new schemes for casual hiring in the R\&D laboratories are disguised.

Following this introduction, the first section of this article presents the relevance of innovative micro and small companies to contemporary capitalism and how Brazilian legislation has promoted their insertion into the GVCs. This discussion will be the basis for placing these start-ups within the logic of financial subordination as required by the GVCs. That analysis will then take place in section two of this article. Section three analyses the Calls for Funds in order to reveal how the incorporation of these start-ups into the rent-seeking logic leads skilled workers to be under the schemes of casual employment as a way to reduce costs in innovation.

\section{A Disguised Putting-out System: Innovative Small Firms in GVCs}

This section is an analysis of how global value chains allow for the reduction of $\mathrm{R} \& \mathrm{D}$ costs through the transfer of their risks and costs to others while they have revenues coming from a set of financial assets. This asset management brings together both the demands for innovation of large corporations and the operations required to have their products and services reach farther and farther end markets (Scherer, 2014). These are the investments that truly support and control the processes and set a pattern of industrialisation based on financial dominance (Harvey, 2004; Guttmann, 2008; Chesnais, 2013). This context has permitted countries of low technological density, such as Brazil, to make use of these assets as a way to access advanced technologies and expand the offer of more value-aggregated products to foreign trade. This expectation has been resetting developmental policies in order to have productive systems that are more appealing to financial capital.

The GVC approach herein aims to highlight how financial freedom has allowed leading companies all over the world to make investments toward juridically autonomous businesses with the potential to diversify their products as a strategy for the expansion of their own consumption markets. These transactions are mostly directed to nation-wide logistics and trade of products (Huws et al., 2009; Cowen 2014). They are of a moderate technological complexity and dependent on foreign technological patents (Nathan, 2020), which represents a new pattern of financial and technological subordination within centre-periphery relations (Cassiolato, 2013).

As claimed by Gereffi (1994), the financial deregulation restructures the transnational productive chains in two interrelated ways: 1 . the producer-driven chains, when the large industry has and controls most parts of the operation from the downstream and upstream of the final product, thus forming oligopolies and driving consumption; and 2. the buyer-driven chains, when a leading trademark coordinates all the phases of the process up to the final consumer, being led by consumption. While the former has industrial capital as its leader, the latter is triggered by 
commercial capital. Liberalised financial capital is the link that connects both by means of two forms of investment that account for the GVC: foreign direct investment (FDI) and the new forms of investment (NFIs) (Sposito and Santos, 2012; Cassiolato, 2013; Chesnais, 2013).

FDI aims at the total or partial control of capital from national companies, as the foreign companies buy or merge with the national ones. In general, this type of investment focuses on large industries with greater potential for internationalisation of global oligopolies, particularly for those industries that belong to the producer-driven chains (Sant Anna, 2017). NFIs refer to control over national companies by foreign corporations whose processes of externalisation do not require direct ownership, licence agreements for use and technical assistance, franchising, contracts and international under-contracts (Sposito and Santos, 2012; Chesnais, 2013). This type of investment prevails within the buyer-driven chains and is responsible for the marketing of the products that come from producer-driven value chains.

After the end of the cycle of privatisation of state companies and subsequent to the implementation of neo-liberal policies in the peripheral countries, NFIs started to be the main vector of direct financial investment. Since then, a vast variety of new intangible monetary assets have increased the number of opportunities for profitable investments that do not require major acquisitions and provide for faster capital reallocation (Guttman, 2008). And this is the portfolio of financial products that account for the core of buyer-driven value chains.

This multi-product financial approach has allowed for the negotiation of real estate values from large corporations in the form of bills of exchanges or stocks. This means that these stocks can be artificially inflated, with no corresponding tangible assets, as they are used upon advanced credit in order to appeal to others. This manoeuvre relies on what is called fictitious capital by Marx - that is, the money generated by speculative difference between the purchase price and the sale price of the shares in the stock market, in a way that is abstract to the production of fixed capital (Guttmann, 2008). With the prevalence of such NFIs, it is possible for any individual to become a shareholder in these companies.

The flows of fictitious capital provide for a new pattern of capital internationalisation, as this capital may finance R\&D activities devoted to the growth of logistics and retail operations by the global companies in order to suit them, in compliance with the legal specificities and demands of the countries in which they are inserted (Scherer, 2014). This finance-driven industrialisation led to a fine interaction between financial and non-financial companies in such a way that it is rather difficult to separate the two (Serfati, 2008). Thus, buyer-driven GVC leading companies have become factoryless goods-producing firms as they restrict their assets to trademarks and patents while their products and services can be produced in different parts of the planet (Bernard and Fort, 2015). These two properties are the ones that support the whole productive chain of the companies, reducing their structure to a virtual and integrated informational system that manages their global production and circulation networks. In fact, shifting the activities to local small-sized firms is a better deal for them than having their own factories and paying taxes.

Due to intense production fragmentation and geographic dispersion caused by this movement, a reliable institutional environment that is also able to provide the management and operation of these processes is essential for the motivation and continued existence of such fictious capital (Harvey, 2001). One of the main central actions for this purpose is the setting of cooperation agreements in $R \& D$ in order to stimulate insertion into the GVCs. Also, leading companies from these chains perceive partnerships as opportunities to expand the consumption of their trademarks and patents as they make use of local available resources that bring costs down (Faustino and Gohr, 2016). In such a context, relational revenues - that is, institutional actions that connect large-sized and local small-sized firms - gain special relevance in the promotion of such partnerships (Olave 
and Amato Neto, 2001).

And it is within this conjuncture that the internationalisation of the so-called innovative micro and small businesses play a strategic role. According to the Brazilian Micro and Small Business Support Service (SEBRAE, 2006: 12), this type of micro and small business represents an interesting partnership for the transnational companies as "their production is flexible and quite attractive for industries with seasonal demand or supply; likely cost reductions for labor-intensive industries; and proximity to markets"; the way to be taken is that of "becoming a supplier for large international companies, engaging in price competition, or the specialization in market niches".

With the retraction of the state from the economy, these transactions have started to be financed by a model of governance supported by public-private partnerships whose objective and main policy is to create institutional mechanisms to support innovation (Conceição and Feix, 2014; Oliveira et.al., 2017). Innovative production is defined as any activity "devoted to the generation of wealth, either by the transformation of knowledge into products or services, or by the generation of knowledge itself and innovation in areas of marketing, production, organization, and others" (Loures, 2015: 93). Different from "lifestyle" entrepreneurship, which relates to that portion of workers who are not in the industrial sector, the policies for innovative entrepreneurship focus on the industry sector in which activities are conceived as a means for accelerated transition from a production-driven and commodity-dominant economy to the innovation-driven stage where conditions are created in order to place small local businesses into the trade and financial path of GVCs (Naretto, Botelho and Mendonça, 2004). The idea is to promote more creative businesses with the potential to lever the national economy and to generate better-skilled and better-paid jobs (Oliveira et al., 2017).

However, as micro and small-sized innovative companies are seen as suppliers for the transnational corporations, they tend to go under the roof of the global value chains, where the processes are of less added value if compared to those responsible for changing consumption patterns (Tenório and Valle, 2012; Wolff, 2019). Thus, these micro and small-sized businesses find themselves subordinate to the technological parameters of global companies as the innovations of the former add value to the latter (Krein and Biavaschi, 2012). This model of small business proves to be a disguised outsourcing system as the relations of subordination to the large companies are camouflaged by the appearance of autonomous small companies (Krein, 2018).

Under this focus, innovative micro and small-sized businesses play the role of handcompanies that are financially subordinated to head-companies (Castillo, 2008) of the buyer-driven GVC and in need of NFIs for externalisation. This subordination is also disguised by governance policies that arrange these ties in a contingent way by means of public-private partnerships in temporary projects for innovation of processes and products of leading corporations. Starting from this apparent autonomy, these innovations become phases of value aggregation for global processes of production without production costs, and they move on to become productive worksites (Huws et al., 2009), whose related cost taxations are outsourced and account for additional advantage.

As a matter of fact, and in an overall perspective, micro and small-sized companies amount to 99.1 per cent of Brazilian legal businesses and account for 52.2 per cent of formal jobs (DataSebrae, 2019). In the software sector, where microbusinesses are innovative, the latest census for the Brazilian market, carried out by the Brazilian Association of Software Companies, shows that Brazil represents 1.8 per cent of the world market in terms of information technology (IT) and 40.7 per cent of the Latin-American market (ABES, 2020). As far as the software market and related services is concerned, the country ranks eleventh worldwide, giving space to the Netherlands and Italy in 2019. Out of 21020 registered companies, 58 per cent of them belong to the distribution 
and trade sector. From this total, 32 per cent perform activities of distribution and marketing and 41.7 per cent are from the area of software-aggregated technical service, totalling 73.7 per cent of the market.

Also, in the segment of software products and services, 84.8 per cent of the demand comes from the national market. Demands for domestic tailor-made software accounts for 9 per cent of this total, while 5.6 per cent are for domestic production for export and 0.6 per cent are for foreign service development. Among the leading services in this market, 93 per cent refer to manufacturing applications, 84.4 per cent are represented by equipment and mobility, and 42.7 per cent refer to software of outsourcing. Smartphones are at the top of the list regarding the market for equipment and mobility with 8.8 per cent of the total, followed by notebooks and desktops, 4.5 per cent and 3.8 per cent respectively. For other segments of the sector, the market is then divided as follows: 16.6 per cent for support services, 14.2 per cent for integration of systems, 10 per cent for consulting and planning, 9 per cent for customised software, 5.5 per cent for exporting services, and 1.4 per cent for software for training (ABES, 2020). These are the less-aggregated value activities in the sector as they do not generate patents; they only provide for parameterisation and customisation.

On the other hand, the segment of development and production of software, of more aggregated value in the sector, performs in an opposite way accounting for only 26.3 per cent of the market. Taking into consideration that there are 5519 companies that work only in this segment, we have 95.3 per cent of them classified as micro or small-sized businesses. Small-sized companies of fewer than a hundred employees represent 47.1 per cent while 48.2 per cent of them are microbusinesses hiring no more than ten employees. Approximately 50 per cent of this market serve companies from the finances, services and telecom, industry and commerce sectors. Also, 78.5 per cent of the software products are developed abroad, 19.4 per cent are local production for domestic consumption and only 2.1 per cent are for export (ABES, 2020).

These data show not only the dependence of the Brazilian software market in relation to foreign technological packages but also the occupation of its labour market by activities that give parameters to and customise their patents - that is, activities that relate to distribution, trade and support, which are of less aggregated value within the sector. The data also allow for the conclusion that large companies are still in operation but in a ubiquitous and diffuse way within most micro and small-sized businesses that, under the command of financial capital, are actively engaged in the global processes of upgrading.

Next, this article addresses how technology-based start-ups are seen as a new category of innovative business, and focuses on their insertion into buyer-driven GVCs.

\section{Start-ups from a GVC Perspective: On-demand Work and Financial Subordination}

Technology-based start-ups are defined as a category of innovative microbusiness of no more than five years of age and devoted to raising investment for the development of replicable and scalable products (Bicudo, 2016). Thus, they fit that kind of micro-sized business for NFI in connection with buyer-driven GVCs. Due to their unpredictable success, these investments are considered venture capital as they share profits as well as losses that may come from that kind of business (Vilela and Santos Jhunior, 2018). This investment is commonly established by short-term corporate alliances open to foreign capital and focused on a common trade project. Such projects are aimed at opening innovations and expansion of large trademarks. For this reason, these partnerships may be typified as a model of modular governance which requires intermediary 
knowledge qualification (Nathan, 2020).

Due to this capacity to attract foreign investment, technology-based start-ups have become the object of several private and public incentive policies in Brazil with the purpose of creating an environment for fund-raising (Audy and Piqué, 2016). At the government level, major programmes include: Start-Up Brasil, promoted by the Ministry of Science, Technology, Innovation and Communications; InovAtiva Brasil and Inovapps, both sponsored by the Ministry of Economy, Industry, Foreign Trade and Services; and incubators generally supported by public universities, and technological parks promoted by municipal policies (Roncaratti, 2017). These initiatives are for the promotion of "innovation ecosystems" defined as a favourable environment for the articulation of national productive systems with policies of innovative entrepreneurship (Audy and Piqué, 2016). The so-called accelerators have an important role in forming these ecosystems as they are a kind of joint-venture-based incubator. In Brazil, the institutionalisation and governance of these relations take place through the Calls for Funds devoted to fostering technology-based startups.

Therefore, the aim is to have the qualified insertion of the country into GVCs through a more effective engagement in foreign trade of components once the incorporation of value-adding services is an indication of better international integration of countries (Scherer, 2014). This scenario led to the passing of specific legislation for start-ups, which were previously regulated by the National Statue of Micro and Small-Sized Firms, instituted in December 2006, as a complement to the law that created the Council for Financial Activities Control (Conselho de Controle de Atividades Financeiras, COAF). The law has been an incentive for this type of businesses as it also instituted the Simple National Taxation Program to exempt them from federal taxes for a period of two years plus a possible two more years as well as a 50 per cent discount on taxes after this period.

Only in April 2019, by enforcement of Law 167, did the start-ups begin to have special treatment compared to other categories of small and medium enterprises (SMEs). The taxation programme - Inova Simples - was a replacement for the National Simple Program with an exclusive automatic system of registration and legislation of start-ups. Tax incentives remained the same and start-ups were more accurately defined and described as innovation-oriented microbusiness with the objective of improving systems, methods or business models for production, services or products under uncertain conditions. Legally, start-ups may be incremental in nature (when they innovate existing products) or they may deal in disruptive technologies (when they create something totally new) (Christensen, 2016; Câmara dos Deputados, 2019). Another important distinction has been their identification as inductor agents of technological advances and generation of employment, and the recognition of risk as being an inherent element for the entrepreneurs of start-ups (art. 65-A, caput).

Start-ups of incremental innovation are the so-called copycat businesses; rather than developing disruptive technologies, they customise those already consolidated in the market. This type of innovation is defined as open; it aggregates value to the technologies using innovative solutions from outside leading companies, which can capture a part of this value. Open innovation is directed to the development of software solutions for services. Unlike software for production, these solutions do not generate patents; they are based on already-patented technological platforms. (Bastos, 2018). In other words, software solutions for services aggregate value to the patents whereas software solutions for products create value as they generate disruptive technologies that will eventually result in patents. Being defined as closed innovations, the disruptive technologies demand industrial secrecy and R\&D time with a high level of codification; they tend to be found in advanced industrialised countries (Nathan, 2020). 
From the perspective of investors, open innovations are more likely to result in scalable products. In this way, production costs are reduced, and risk capital is compensated by a better guarantee of sales to large markets (Ishizaka and Lizarelli, 2016). In Brazil, incentives to copycat start-ups are an indication that the financing of production led to the dependence of the innovation systems on foreign patents (Roncaratti, 2017; Bastos, 2018). This phenomenon is also explained by the lack of opportunities for formal jobs in countries of low industrialisation (Roncaratti, 2017).

Incentives to start-ups have been a strategy to absorb a skilled workforce from the industrial sector through putting-out systems in R\&D laboratories. This was possible due to the restructuring of productive chains following the Toyota methods that replaced large warehouses with lean production under just-in-time work (Cowen, 2014). As for the copycat start-ups, these demands were triggered by NFIs directed by buyer-driven GVCs profiting from ideas that can generate value to technologies already found in the market and likely to result in scalable products. The connection between these start-ups and the NFIs takes place with the financing of projects and a pre-defined time for execution. Calls for Funds are one of the main instruments for this purpose.

This connection economy (Robichaud, 2013) gave birth to the piecework wage that is here exemplified by projects submitted to those Calls for Funds. The piecework wage was the first kind of employment in the mercantilist economic model that gave rise to capitalism. According to Marx (1984 [1867]), the piecework wage is that model that best meets capital's aim of controlling work with low production costs. It is known that this kind of wage forces workers to produce faster, reduces work costs and does not define legal limits for work shifts.

Modern industry was gestated within this putting-out-system. During the colonial era and before the industrial time, capitalist success was linked to quick access to affordable inputs and to a skilled manufacturing workforce. Under the putting-out-system, the capitalist was the trader of these factors since his profits came from his circulation advantage, which allowed him to buy raw materials in cheaper markets and sell the final products in more expensive markets. Therefore, rather than production means, circulation used to be the variable to profit. The current liberalisation of the transit of capital between countries has restored this capacity, but now within a scenario of large concentrated capital, favouring a new form of putting-out system. The difference from former capitalism is that nowadays this transit occurs on a global scale due to information and communication technologies (ICTs). ICTs have enabled circulating capital to flow worldwide in search of knowledge to serve as a commodity that may add value to the means of production.

This accumulation of capital by circulation designed a lean industrial sector, circumscribed by strategic functions, such as the production of patents, financial management and diversification of businesses, in order to keep its dominion over the world market (Bernard and Fort, 2015). All the other activities that could result in new inputs, add value and expand consumption are externalised and converted into profitable businesses. In this context, global companies are defined as connectors and organisers of global flows of industrial and commercial capital through the control of share capital, thus blurring the difference between finances, commerce and industry (Cassiolato, 2013). They are factoryless firms producing goods; they do not belong to a plant; they operate under a virtual, fragmented and financial logistics in which the whole world is the locus for adding value (Bernard and Fort, 2015).

The modus operandi of this new putting-out system has a central characteristic of production modularisation; a process that can be employed in new components and functions linked to a technological database which does not alter its framework (Moro and Cauchick-Miguel, 2018). Modularisation turned closed innovation into open innovation and allowed for performance improvements, automation and management at several levels of the production chain based on the same system. These improvements refer to development and diversification of products and 
services and their integration into logistics processes of transport, storage and trade (Cowen, 2014). Therefore, production modularisation promoted putting-out systems by externalising specific activities in eventual suppliers compensated by specific tasks or projects in seasonal and on-demand work.

The difference between this type of externalisation and the putting-out system of Marx's time is that, beyond appropriating raw materials, controlling their distribution, specifying the project and setting the deadline, the large industry also controls the design of the working tools. Thus, this system is able to include productive processes that come outside its boundaries and also has a skilled workforce that can use such tools at any time and in any space by means of direct financial investment from the free market. Furthermore, informatisation also allowed for automated management of the processes in digital platforms and their standardisation - something impossible in the artisan conditions present at the origins of capitalism.

A considerable part of the workforce demanded by these processes has been re-allocated to technology-based start-ups linked to casual jobs imposed by financial capital. For this reason, these start-ups are seen as a fruitful base for understanding industrialisation that is guided by finances and the new piecework wage it gave birth to. In this sense, Calls for Funds for start-ups seem to be a way to connect a skilled workforce to the technological parameters of transnational patents and to investors willing to expand their markets through innovation. However, discontinued networks from institutional arrangements, partnerships and sources of funding blur the subordination of start-ups to those that take appropriation of their results. The analysis of Calls for Funds in the following section shall clarify these relations as well as reveal them as a form of piecework wage financially subordinate to the dynamics of the global value chains.

\section{Calls for Funds: From Anchor Industries to Seed Capital}

Calls for Funds for technology-based start-ups are the connection between large and small-sized companies through cross-fertilisations - the appropriation of knowledge from diverse origins to produce innovative solutions for the market. They are a kind of joint venture, also called opportunistic alliances. Their purpose is to make competitive advantages possible for businesses that are not part of the alliance by forming temporary partnerships in order to expand markets with the creation of new products and services (Olave and Amato Neto, 2001: 292).

Such alliances are "partners of distribution", defined as "producers sharing costs of physical structure and human resources for the sharing and distribution of products in the consumption market" (SEBRAE, 2006: 124). Therefore, they have a medium level of commitment to the international market since their products are aimed at serving domestic markets. In this case, internationalisation takes place by giving local firms easy access to channels of distribution from foreign companies that aim to gain internal markets (SEBRAE, 2006).

The analysis of two Calls for Funds of this nature illustrates the way they institutionalise the temporary connection between the financed start-ups and 1) leading companies that aim to improve their productivity, and 2) the investors that aim to profit from potential innovations. Thus, these Calls not only reduce transaction costs, but they also perform the role of negotiator for a just-in-time workforce that is skilled in such innovations. In other words, they institutionalise a system of virtual factoryless goods-producing firms as found in buyer-driven GVCs.

In the first case, the demand for products and services comes directly from the industry sector and aims to improve already existing processes, products and services. In the second case, random private investors demand innovative solutions for expanding the Internet services provided by the so-called smart factories (digital platforms, Internet of things, apps). 


\section{Call for Funds by the System of Industry}

The Innovation Call for the industry sector (henceforth, the SI Call) was launched by the Brazilian System of Industry ${ }^{2}$ in May 2018. The objective was to "fund the development of innovative solutions for Brazilian industry, be they new or innovative products, processes or services" in order to promote "an increase in productivity and competitiveness for Brazilian industry" through the funding of technical working time, raw materials and other inputs (SEBRAE, 2018: 2). As in the words of this Call, these projects must present "solutions to technological challenges in a stage that demands technological development or improvement for tests of concept, pilot plants and insertion of solutions into the market" (SEBRAE, 2018: 4). Themes covered by the Call included: a) technological innovation for large and medium-sized firms; b) technological innovation for micro and small-sized firms, individual micro entrepreneurship and technology-based start-ups; and c) industrial entrepreneurship - large firms and start-ups.

Start-ups - named Proposing Firms - are described as companies with up to five years of existence whose annual income is lower than 4.8 million reais and which are registered as a corporate. The investing companies - named Anchor Institutions - are represented by medium and large-sized companies committed to making resources available for the execution of innovation projects of specific themes of interest (SEBRAE, 2018: 2). The Call also allowed for the possibility of forming partnerships with national and international centres of research. All the stakeholders should share duties and risks in the selected projects (SEBRAE, 2018: 3).

The projects should last no longer than twenty-four months, with no time extension allowed. The largest budget for each project was in the amount of 400000 reais, with a 75 per cent share for the financial counterpart and 25 per cent share for the Regional Departments of SENAI that were involved in the working plans. The compulsory share of 50 per cent was for Anchor Institutions and compulsory 25 per cent share of the amount for the project selected by the medium-sized firms. The proposing start-ups had a share in the amount of 10 per cent of the budget for the project with the possibility of 10 per cent more if they reached the top rank in project classification. SEBRAE was responsible for giving these start-ups access to the infrastructure and scientific-technological knowledge of SENAI Institutes of Innovation and Technology.

The Anchor Institutions were allowed to "define the conditions to participate in the project, be it as a shareholding in the Proposing Firm (start-ups), with Royalties or others", with "full autonomy to select the Proposing Firms at all phases of the process of selection and being also allowed to choose none" (SEBRAE, 2018: 37). The Anchor Institutions, therefore, were the main actors of this Call as they were not only responsible for "specific calls, negotiation and validation of the rules to establish the values for the projects" but were also in charge of the management of the projects together with SENAI and SESI (SEBRAE, 2018: 3). Thus, the Anchor Institutions played the temporary role of bosses for the selected start-ups once the specific demands of the project were identified and agreed.

Although these innovations were strictly directed to the demands of the Anchor Institutions, the proposing start-ups also had to assume the risks of the projects, evidencing an advantageous business model that reduced $\mathrm{R} \& \mathrm{D}$ costs. As the costs are subsidised by the national industry systems and part of the resources come from the state and from the start-ups themselves, the

\footnotetext{
2 The institutions that comprise this system are: SEBRAE, the Brazilian Service for Support to Micro and Small-Sized Companies; SESI, Social Service of the Industry; and SENAI, the National Service for Industrial Learning.
} 
investments in innovation would be higher than if they were completely financed by the Anchor Institutions. Therefore, although legally independent, these start-ups are directly subordinated to the Anchor Institutions, both in terms of remuneration and in terms of direct participation in adding value to their processes and products. This is the way in which innovation costs are externalised and converted in stages of adding value to the processes of innovation of other industries.

\section{Call for Funds from FINEP}

The FINEP Call for Start-ups, the Investment Program in Innovative Start-ups, was launched in July 2017 and promoted by the Financier of Innovation and Research (FINEP). FINEP is a Brazilian public entity linked to the Ministry of Science, Technology, Innovation and Communications whose objective is "to transform Brazil through innovation" by funding basic research and even the preparation of products for the market. Its action profile is "to operate throughout the whole chain of innovation with a focus on strategic, structuring and impactful activities for Brazil's sustainable development". Resources come from the National Fund of Scientific and Technological Development and from cooperation agreements with and by other ministries, entities and sectoral institutions (FINEP, 2020).

This Call was meant to provide resources for technology-based start-ups in their initial phase - considered to be the most critical and expensive - in order to create skilled jobs. Also, another purpose of the Call was to promote "the development of a seed capital market in Brazil, sharing risks associated with investments in technology-based firms with private investors" (FINEP, 2017: 1). Seed Capital is the initial investment in start-ups by individuals or companies to subsidise the development of technological innovations. Such investment is considered risky because it is made in the prototype development phase, when there is no guarantee of results. The Call, then, was an incentive for the "ecosystem of innovation" in the country through a policy of governance based on public-private partnerships.

The total value of the Call amounted to 50 million reais (up to 1 million per project). Two rounds of investment were expected for the distribution of the "total amount of funds including the budget of FINEP plus that of investors interested in the investment" (FINEP, 2017: 16). Each round could support up to twenty-five start-ups. The themes included: Education; Sustainable Cities; Fintech; Internet of Things; Creative Economy; Energy; Defence; Mining; Oil; Advanced Manufacturing; Biotechnology; Aggrotech; Chemistry; Building Information Modelling Solutions.

Unlike the SI Call, the resources were directly transferred to the proposing start-ups and did not have to meet the demands of specific companies. The start-ups, in this case, are financially subordinate to angel-investors, that is, national or international individuals with seed-capital investments. Counterpart to angel-investors was their participation in returns from the selected projects under the same conditions of FINEP and proportionally rated according to the investment in each round. Both FINEP and the angel-investors could buy the selected start-ups - secured in the contract - according to the percentage of investment made by each party (FINEP, 2017: 18).

In this analysis, the following eligibility criteria for the start-ups were considered: 1) registration as a private limited company or stock corporation; 2) "capacity for the development of a new product, service or process upon the integration of existing technologies and the addition of a new development"; and 3) projects being "at least in the prototype or test phase and, preferably, having been already traded but not in the phase of conception of idea or research" (FINEP, 2017: 5). Start-ups presenting letters of commitment of investments higher than 50000 reais would score better in the selection process (FINEP, 2017: 6).

In Brazil, a business that is are registered as a private limited company may have a sole owner. 
This legal condition situation may lead to a situation in which an informal workforce could be seen as an independent firm - that is, it could disguise freelance jobs as independent firms (Krein, 2018). The statute for listed stock corporations exempts shareholders from any responsibility for unsuccessful projects. Therefore, their participation is limited to owning shares, and those who submit projects are the ones who take the major risks. In this sense, the concern of the current federal government is to set up a regulatory framework for the "creation of tax incentives for investors and mechanisms to avoid liabilities in case of a start-up bankruptcy" (Oliveira, 2019: 2).

In an article published in Folha de S. Paulo newspaper, the coordinator of the sub-committee for labour issues stated that the main objective of the group was to create "mechanisms that may bring to the formal market, with no obstacles for them, suppliers of services that are partners with the start-ups (as in the Uber model for drivers)". Workers are registered as corporates in order to appeal to investors who will thus be exempted from labour taxation. According to a statement made by the sub-committee coordinator for tax issues, the goal of that group is "to reduce the risks investors may have for eventual labor and tax liabilities with unsuccessful start-ups" as they are "risky businesses with a high probability of not achieving their goals" (Oliveira, 2019: 2).

The analysis of both Calls showed that they have met these objectives as they had foreseen the possibility of start-ups generating a just-in-time casual employment network. This scenario is a result of production modularisation in which phases of the productive process are externalised to casual workers according to the demand. Therefore, these Calls have served to disguise processes of externalisation subordinated to leading companies through a false, although legal, condition of turning skilled workers into corporates.

In sum, the analysis of these Calls led to the conclusion that the start-ups that submitted to the Calls had a rather limited probability of becoming large businesses, although this might be the dream of many of them (Maia, 2019). They tend rather to just expand casual working ties. Being an entrepreneurship of uncertainties, a return from their projects can only be obtained through the scalability of their products. The tendency seems to be that of never changing their status of microsized business as they do not have enough capital for large-scale production. In this context, startups remain with only two options for survival: 1) apply in Calls for Funds forever, or 2) sell their business to a large-sized firm. Even if start-ups receive a good price for the sale, the resulting profits for the trade in scale will be always higher. So, successful selections by the Calls may be bought as capital assets while budgets for start-ups will be used for wages. In other words, investors will harvest the seeds and the start-ups will remain with just-in-time labour.

\section{Conclusion}

The article has tried to clarify the casual employment relations that add value to trademarks and patents of the leading companies in global value chains through new forms of investment generated by the liberalisation of economies. For this purpose, this article analysed the funding policies for the Brazilian system of innovation within the idea of stimulating industrialisation nationwide through the insertion of higher-added-value activities into the GVCs and the connection of national innovative microbusinesses to the international systems of indirect investment. The analysis showed that this model of development, which is conditioned to financial capital, contributes to the subordination of such activities to the logics of exploration and extraction of value inside these chains. Thus, the model has been used to increase foreign technological patents rather than to promote disruptive technologies that are able to compete in markets of high added value.

This scenario is the result of the modularisation of digital platforms which, in turn, allowed 
for the physical fragmentation of production by patented software packages that enable them to be innovative without changing their framework. The modularisation of production was an opportunity for leading companies from the GVCs to externalise activities that could add value within the pattern of a global putting-out system aimed at appropriating and exploring innovative ideas that may lead to new profitable businesses. This strategy is made possible by the financial deregulation for direct investment in innovation activities.

The research demonstrated that the Calls for Funds for technology-based start-ups represent one of the main ways in which the financial capital that supports the GVCs has entered certain countries. Such Calls are a means for connecting corporate demands with autonomous workers, and thus institutionalising outsourcing processes that are disguised as innovation laboratories for leading companies that make use of a just-in-time workforce. This dynamic has reinvented the workpiece wage - a condition that has been hidden under the statute for independent microbusinesses and has allowed for the evasion of labour taxation.

Under the appearance of autonomous firms, the start-ups are presented as partners of their investors when, in fact, they are subordinate to them as they comply with investors' market and productivity demands as well as with the rules on how to meet such demands. In addition to the reduction of labour costs through innovation processes, this strategy also shares expenses and project risks with the start-ups that were selected in the Calls. From this point of view, policies of governance and innovative entrepreneurship are means for the leading companies in GVCs to obtain a cheap and skilled workforce, with subsided funds from the state.

This paradigm of industrialisation as led by the financial sector replicates, on new bases, the old strategy of spatial decentralisation of capital in search of new places in which to expand the global processes of value-adding with cheaper production costs. Thus, rather than promoting sustainable development, the economic model for the insertion of a country into global value chains has taken the form of dependence on financial capital, which leads to an even stronger dependence on foreign technologies. In this context, casual work has been used as the trading currency to make less industrialised countries, such as Brazil, more appealing to the dynamics of global value chains.

\section{References}

Anner, M. (2011) Solidarity Transformed: Labor's Responses to Globalization and Crisis in Latin America. Ithaca, NY: Cornell University Press.

Associação Brasileira de Empresas de Software (ABES) (2020). Mercado Brasileiro de Software: panorama e tendências. São Paulo: ABES. https://abessoftware.com.br/dados-do-setor/ [accessed 15 February 2021].

Audy, J. and J. Piqué (2016) Dos parques cientificos e tecnológicos aos ecossistemas de inovação: desenvolvimento social e econômico na sociedade do conbecimento. Brasília: ANPROTEC. https:/ /informativo.anprotec.org.br/ebookserie-tendencias-dos-parques-cientificos-e-tecnologicos-aos-ecossistemas-de-inovacao [accessed 16 December 2019].

Bastos, T.F. (2018) Gênese e dinâmica do setor de software em Londrina (PR). Master's thesis. Londrina: Universidade Estadual de Londrina. http://www.bibliotecadigital.uel.br/document/?code= vtls000222806 [accessed 25 September 2019].

Bernard, A.B. and T.C. Fort (2015) Factoryless Goods Producing Firms. American Economic Review, 105(5): 518-23. http://www.superbosses.com/images/uploads/faculty/teresa-fort/Bernard Fort FGPFs 2015.pdf [accessed 15 February 2021]. 
Bicudo, L. (2016) O que é uma startup? https://www.startse.com/noticia/startups/18963/afinal-o-que-euma-startup [accessed 20 October 2019].

Câmara dos Deputados (2019) Lei Complementar n 167, de 24 de abril de 2019. https://www2.camara.leg.br/ legin/fed/leicom/2019/leicomplementar-167-24-abril-2019-788009-publicacaooriginal-157795pl.html [accessed 28 January 2020].

Cassiolato, J.E. (2013) Empresas transnacionais e o desenvolvimento tecnológico brasileiro: uma introdução ao artigo "Present International Patterns of Foreign Direct Investment: Underlying Causes and Some Policy Implications for Brazil". Revista de Economia Contemporânea, 17(3): 365-375. https://www.scielo.br/pdf/rec/v17n3/v17n3a01.pdf [accessed 14 July 2019].

Castillo, J.J. (2008). Las fábricas de software em España. Organización y división del trabajo: el trabajo fluido em la sociedad de la información. Política es Sociedade, Revista de Sociologia Politica, 7(13): 35-108. https://periodicos.ufsc.br/index.php/politica/article/view/2175-7984.2008v7n13p35 [accessed 19 January 2020].

Chesnais, F. (2013) Present International Patterns of Foreign Direct Investment: Underlying Causes and Some Policy Implications for Brazil. Revista de Economia Contemporânea, 17(3): 377-422. https://www.scielo.br/scielo.php?script=sci arttext\&pid=S1415-98482013000300001 [accessed 14 July 2019].

Christensen, C.M. (2016) The Innovator's Dilemma: When New Technologies Cause Great Firms to Fail. Brighton, MS: Harvard Business Review Press.

Conceição, C.S. and R.D. Feix (eds.) (2014) Elementos conceituais e referências teóricas para o estudo de Aglomerações Produtivas Locais. Porto Alegre: FEE. https://arquivofee.rs.gov.br/wp-content/uploads/2014/11/ 20141125e-book-completo.pdf [accessed 23 May 2019].

Cowen, D. (2014) The Deadly Life of Logistics: Mapping the Violence of Global Trade. Minneapolis, MN: University of Minnesota Press.

DataSebrae (2019) PIB. https://dataSEBRAE.com.br/pib [accessed 20 January 2020].

Faustino, C.A. and C.F. Gohr (2016) Rendas relacionais como fonte de vantagem competitiva: um estudo de caso em uma empresa calçadista do estado da Paraíba. Revista Gestão Industrial, 12(3): 1-18. https://periodicos.utfpr.edu.br/revistagi/article/view/3965 [accessed 14 March 2019].

Financiadora de Estudos e Projetos (FINEP) (2017) Programa de Investimento em Startups Inovadoras. http://www.FINEP.gov.br/chamadas-publicas/chamadapublica/614 [accessed 12 October 2018].

Financiadora de Estudos e Projetos (FINEP) (2020). About Finep. Brasília: FINEP. http://www.finep. gov.br/about-finep [accessed 20 February 2020].

Flecker, J. (ed.) (2016) Space, Place and Global Digital Work. London: Palgrave Macmillan.

Gereffi, G. (1994) The Organization of Buyer-Driven Global Commodity Chains: How U.S. Retailers Shape Overseas Production Networks. In Commodity Chains and Global Capitalism, edited by G. Gereffi and M. Korzeniewicz. Westport, CT: Praeger.

Gereffi, G. (1999) International Trade and Industrial Upgrading in the Apparel Commodity Chain. Journal of International Economics, 48(1): 37-70.

Gereffi, G. (2005) The Global Economy: Organization, Governance and Development. In Handbook of Economic Sociology, edited by N. Smelser and R. Swedberg. Princeton, NJ: Princeton University Press and Russel Sage Foundation.

Gereffi, G., J. Humphrey and T. Sturgeon (2006) The Governance of Global Value Chains. Review of International Political Economy, 12(1): 78-104.

Guttmann, R. (2008) Uma introdução ao capitalismo dirigido pelas finanças. Novos Estudos CEBRAP, 82: 11-33. https://www.scielo.br/pdf/nec/n82/01.pdf [accessed 11 November 2019].

Harvey, D. (2001) Spaces of Capital: Towards a Critical Geography. Edinburgh: Edinburgh University Press.

Harvey, D. (2004) The New Imperialism. Oxford: Oxford University Press. 
Hopkins, T. and I. Wallerstein (1986) Cadeias de Commodities na Economia Mundial Antes de 1800. Revisão, 10(1): 157-170.

Huws, U., S. Dahlmann, J. Flecker, U. Holtgrewe, A. Schönauer, M. Ramioul and K. Geurts (2009) Value Chain Restructuring in Europe in a Global Economy. Brussels: Katholieke Higher Institute of Labour Studies, University of Leuven. https://limo.libis.be/primo-explore/fulldisplay?docid=LIRIAS1897699 \&context $=$ L\&vid $=$ Lirias\&search scope $=$ Lirias\&tab=default tab\&lang=en US\&fromSitemap $=1$ [accessed 18 July 2019].

Ishizaka, A.Y. and F.L. Lizarelli (2016) Mensuração da inovação incremental e radical de produtos e processos: uma revisão bibliográfica sistemática [artigo apresentado no encontro]. Trigésimo sexto Encontro Anual de Engenharia de Produção, João Pessoa, Paraíba, Brasil. http://www.abepro.org.br/biblioteca/TN STO 233358 29199.pdf [accessed 20 February 2020].

Kaltmeier, O., A. Tittor, D. Hawkins and E. Rohland (eds.) (2020) The Routledge Handbook to the Political Economy and Governance of the Americas. London: Routledge.

Krein, J.D. and M. Biavaschi (2012) Condições e relações de trabalho no segmento das micro e pequenas empresas. In Micro e Pequenas Empresas Mercado de Trabalho e Implicação para o Desenvolvimento, edited by A. Santos, J.D. Krein and A.B. Calixtre. Rio de Janeiro: IPEA. https://www.ipea.gov.br/portal $\angle$ index.php?option $=$ com content\&view $=$ article\&id $=16690$ [accessed 10 December 2019].

Krein, J.D. (2018) O desmonte dos direitos, as novas configurações do trabalho e o esvaziamento da ação coletiva: consequências da reforma trabalhista. Tempo Social, 30(1): 77-104. https://www.scielo.br Lscielo.php? script $=$ sci abstract\&pid $=$ S0103-20702018000100077\&lng $=$ pt\&nrm $=$ iso $\quad[$ accessed 12 December 2019].

Loures, H.L. (2015) Empreendedorismo: uma visão política de seus fundamentos. Negócios em Projęão, 6(2): 93-104. https://seer.imed.edu.br/index.php/revistasi/article/viewF\%20ile/612/522 [accessed 29 November 2019].

Maia, M.M. (2019) Como as start-ups crescem? Performances e discursos de empreendedores à procura de capital. Revista Brasileira de Ciências Sociais, 34(99): 1-17. https://www.scielo.br/scielo.php?script Esci arttext\&pid=S0102-69092019000100513 [accessed 14 October 2019].

Marx, K. (1984 [1867]). O salário por peça. In O Capital: crítica da economia política, edited by Karl Marx. São Paulo: Abril Cultural.

Moro, S.R. and P.A Cauchick-Miguel (2018). Adoção da arquitetura modular na inovação de produtos: uma análise preliminar da literatura. GEPROS. Gestão da Produção, Operações e Sistemas, 13(2): 89-111. https://revista.feb.unesp.br/index.php/gepros/article/view/1847 [accessed 25 January 2019].

Naretto, N., M.R. Botelho and M. Mendonça (2004) A trajetória das políticas públicas para pequenas e médias empresas no Brasil: do apoio individual ao apoio a empresas articuladas em arranjos produtivos locais. Planejamento e Políticas Públicas, 27: 61-115. https://www.ipea.gov.br/ppp/index.php/PPP Larticle/view/51 [accessed August 2019].

Nathan, D. (2020) Knowledge, Oligopoly and Labour in Global Value Chains. Global Labour Journal, 11(2): 134-151. https://mulpress.mcmaster.ca/globallabour/article/view/3815 [accessed 16 February 2021].

Olave, M.E.L and J. Amato Neto (2001) Redes de cooperação produtiva: uma estratégia de competitividade e sobrevivência para pequenas e médias empresas. Gestão \& Produção, 8(3): 289-303.

Oliveira, F. (2019) Governo quer marco legal para desburocratizar mercado de startups. Folha de S. Paulo, 12 março 2019. https://www1.folha.uol.com.br/mercado/2019/03/governo-quer-marco-legal-paradesburocratizar-mercado-de-startups.shtml [accessed 1 April 2019].

Oliveira, I.T.M, F.L. Carneiro and E.B. Silva Filho (2017) Cadeias globais de valor, politicas públicas e desenvolvimento. Brasília: IPEA. https://www.ipea.gov.br/portal/index.php?option=com content\&view =article\&id=31265 [accessed 5 December 2019].

Palma, G. (1978) Dependência: uma teoria formal do subdesenvolvimento ou uma metodologia para a análise de situações concretas de subdesenvolvimento? Desenvolvimento Mundial, 6(1): 881-924. 
Patel-Campillo, A. (2010) Rival Commodity Chains: Agency and Regulation in the US and Colombian Cut Flower Agro-industries. Review of International Political Economy, 17(1): 75-102.

Robichaud, K. (2013) The Connection Economy. https://www.payette.com/architecture-forum/theconnection-economy/\#: : text $=$ What $\% 20$ is $\% 20$ the $\% 20$ connection $\% 20$ economy, $\% 2 \mathrm{C} \% \mathrm{E} 2 \% 80 \%$ 9D \%20like $\% 20$ the $\% 20$ industrial $\% 20$ economy [accessed 18 July 2019 ].

Roncaratti, L. S'A. (2017) Incentivos a startups no Brasil: os casos do Startup Brasil, InovAtiva e InovApps. In Inovação no setor público: teoria, tendências e casos no Brasil, edited by P. Cavalcante, M. Camões, B. Cunha and W. Severo. Brasília: IPEA. http://repositorio.ipea.gov.br/bitstream/11058/8800/1/Incentivos\% 20a\%20Startups $\% 20$ no $\% 20$ Brasil.pdf [accessed 10 December 2019].

Sant Anna, E.P. (2017) O investimento externo direto no Brasil durante o governo FHC (1995-2002). Observatorio de la Economia Latinoamericana, 229: 1-6. https://ideas.repec.org/a/erv/observ Ly2017i22947.html [accessed 5 December 2019].

Scherer, A.F. (2014) Cadeias de valor e cadeias globais de valor. In Elementos conceituais e referências teóricas para o estudo de aglomeraçôes produtivas locais, edited by C.S. Conceição and R.D. Feix. Porto Alegre: FEE. https://arquivofee.rs.gov.br/wp-content/uploads/2014/11/20141125e-book-completo.pdf [accessed 23 May 2019].

SEBRAE (2018) Edital de Inovação para a Indústria 2018: suas ideias nas mãos certas. Portal SEBRAE, 19 junho 2018. https://www.SEBRAE.com.br/sites/PortalSEBRAE/ufs/am/artigos/edital-de-inovacao-paraa-industria-2018,cf0c60538c814610VgnVCM1000004c00210aRCRD [accessed 25 February 2020].

SEBRAE (2006) Internacionalização das Micro e Pequenas Empresas: oportunidades sugeridas pela experiência internacional (Relatório Final). https://bibliotecas.SEBRAE.com.br/chronus/ARQUIVOS CHRONUS Lbds/bds.nsf/EFF1F117F3D42C9183257546007523BF/\$File/NT0003DBDE.pdf [accessed 25 February 2020].

Serfati, C. (2008) Financial Dimensions of Transnational Corporations, Global Value Chains and Technological Innovation. Journal of Innovation Economics \& Management, 2(2): 35-61. https://www.cairn.info/revue-journal-of-innovation-economics-2008-2-page-35.htm [accessed 22 July 2019].

Sposito, E.S. and L.B. Santos (2012) O capitalismo industrial e as multinacionais brasileiras. São Paulo: Outras Expressões.

Tenório, F.G. and R. Valle (2012) Fábrica de software. Rio de Janeiro: Editora FGV.

Vilela, N.S. and R. Santos Jhunior (2018) Alianças Estratégicas e Vantagens Competitivas: uma abordagem teórico-empírica sob a ótica da visão baseada em recursos. Journal of Perspectives in Management, 2(1): 2131.

Wolff, S. (2019) Cadeias globais de valor no contexto do empreendedorismo e governança urbana: um novo enfoque à questão da precarização do trabalho no capitalismo contemporâneo. In Trabajo y capitalismo: relaciones y colisiones socials, edited by R. Antunes, A. Bialakowsky, F. Pucci and M. Quiñones. Buenos Aires: Teseo. https://www.teseopress.com/trabajoycapitalismo [accessed 14 November 2019].

\section{BIOGRAPHICAL NOTE}

Simone WolfF is Associate Professor at the Department of Social Sciences and at the Graduate Program in Sociology at the University of Londrina (UEL), Brazil. This article is the result of her post-doctoral internship, carried out at the Institute of Economics of the University of Campinas (UNICAMP) under the supervision of Dr José Dari Krein in 2021. [Email: swolff@uel.br] 